\title{
A new species of Gnaphosa Latreille, 1804 (Aranei: Gnaphosidae) from Western Mongolia
}

\author{
Новый вид пауков рода Gnaphosa Latreille, 1804 (Aranei: \\ Gnaphosidae) из Западной Монголии
}

\author{
Alexander A. Fomichev ${ }^{1,2}$, Yuri M. Marusik ${ }^{3,4} \&$ Mikhail M. Omelko $^{5,6}$ \\ А.А. Фомичев ${ }^{1,2}$, Ю.М. Марусик ${ }^{3,4}$, М.М. Омелько ${ }^{5,6}$

\footnotetext{
${ }^{1}$ Novosibirsk State Pedagogical University, Vilyuiskaya 28, Novosibirsk 630126, Russia. E-mail: a.fomichov@mail.ru

${ }^{2}$ Institute of Systematics and Ecology of Animals, SB RAS, Frunze str., 11, Novosibirsk 91, 630091, Russia.

${ }^{3}$ Institute of Biological Problems of the North, RAS, Portovaya Str. 18, Magadan 685000, Russia. E-mail: yurmar@mail.ru

${ }^{4}$ Zoological Museum, University of Turku, FI-20014 Turku, Finland.

${ }^{5}$ Gornotaezhnaya Station FEB RAS, Gornotaezhnoe Vil., Ussuriysk Dist., Primorski Krai 692533, Russia. E-mail: omelkom@gmail.com ${ }^{6}$ Far Eastern Federal University, Sukhanova 8, Vladivostok 690950, Russia.

${ }^{1}$ Новосибирский государственный педагогический университет, Вилюйская 28, Новосибирск 630126, Россия.

${ }^{2}$ Институт систематики и экологии животных, СО РАН, Фрунзе 11, Новосибирск 91, 630091, Россия.

${ }^{3}$ Институт биологических проблем Севера ДВО РАН, Портовая 18, Магадан 685000. Россия.

4 Зоологический музей, Университет Турку, FI-20014 Турку, Финляндия.

${ }^{5}$ Горнотаёжная станция им. В.Л. Комарова ДВО РАН, с. Горнотаёжное, Уссурийский район, Приморский край 692533, Россия.

${ }^{6}$ Дальневосточный Федеральный университет, Суханова 8, Владивосток, 690950, Россия.
}

KEY WORDS: spider, new species, Palaearctic, Mongolia.

КЛЮЧЕВЫЕ СЛОВА: паук, новый вид, Палеарктика, Монголия.

ABSTRACT. A new species of ground spider, Gnaphosa ustyuzhanini sp.n. is described based on two males from western Mongolia. The new species belongs to the muscorum group and can be easily differentiated from other species within the group by the shape of the tibial and median apophyses and also by the shape of the embolus.

РЕЗЮМЕ. На основании двух самцов описан новый вид пауков Gnaphosa ustyuzhanini sp.n. из Западной Монголии. Новый вид принадлежит к группе видов тuscorum и отличается от представителей группы формой отростка голени, медиального отростка и эмболюса.

\section{Introduction}

Gnaphosa is a large genus with 141 described species [Platnick, 2013] distributed mainly in the Holarctic. It is a rather well studied genus thanks to several revisional studies in the Palaearctic and Nearctic [Ovtsharenko et al., 1992; Platnick \& Shadab, 1975; Song et al., 2004]. So far, 16 Gnaphosa species have been recorded from Mongolia. All were reported in the following papers: Loksa [1965], Ovtsharenko et al. [1992], Marusik [1993], Marusik \& Logunov [1995, 2006], Marusik \& Koponen [2001]. Although the genus is well studied in Mongolia, study of recently collected material from western Mongolia revealed a new spe- cies. The description of this undescribed species is the main aim of this paper.

\section{Material and methods}

Specimens were photographed using an Olympus Camedia E-520 camera attached to an Olympus SZX16 stereomicroscope and AxioCam MRc5 (Zeiss) camera attached to a Stemi $2000-\mathrm{C}$ stereomicroscope. The images were montaged using "CombineZM" and "Helicon focus 3.10" image stacking software. Photographs were taken in dishes of different sizes with paraffin in the bottom. Different sized holes were made in the paraffin to keep the specimens in the correct position. All measurements are given in $\mathrm{mm}$. Abbreviations used in the text are as follows: $\mathrm{d}$ - dorsal, $\mathrm{p}$ - prolateral, $\mathrm{r}$ - retrolateral, v — ventral; all applied to leg spination.Type material will be deposited in the Institute of Systematics and Ecology of Animals, SB RAS, Novosibirsk (ISEA).

\section{Gnaphosa ustyuzhanini sp.n.}

Figs 1-10.

ETYMOLOGY. The specific name is a patronym in honour of the prominent Russian lepidopterologist Petr Ustyuzhanin (Novosibirsk).

TYPE MATERIAL. Mongolia: Holotype $0^{7}$ Chovd Aimag, Arshantyn-Nuruu Mountain Range, Mogoin-Ulan-Ula Mt., $46^{\circ} 19^{\prime} \mathrm{N}$, 


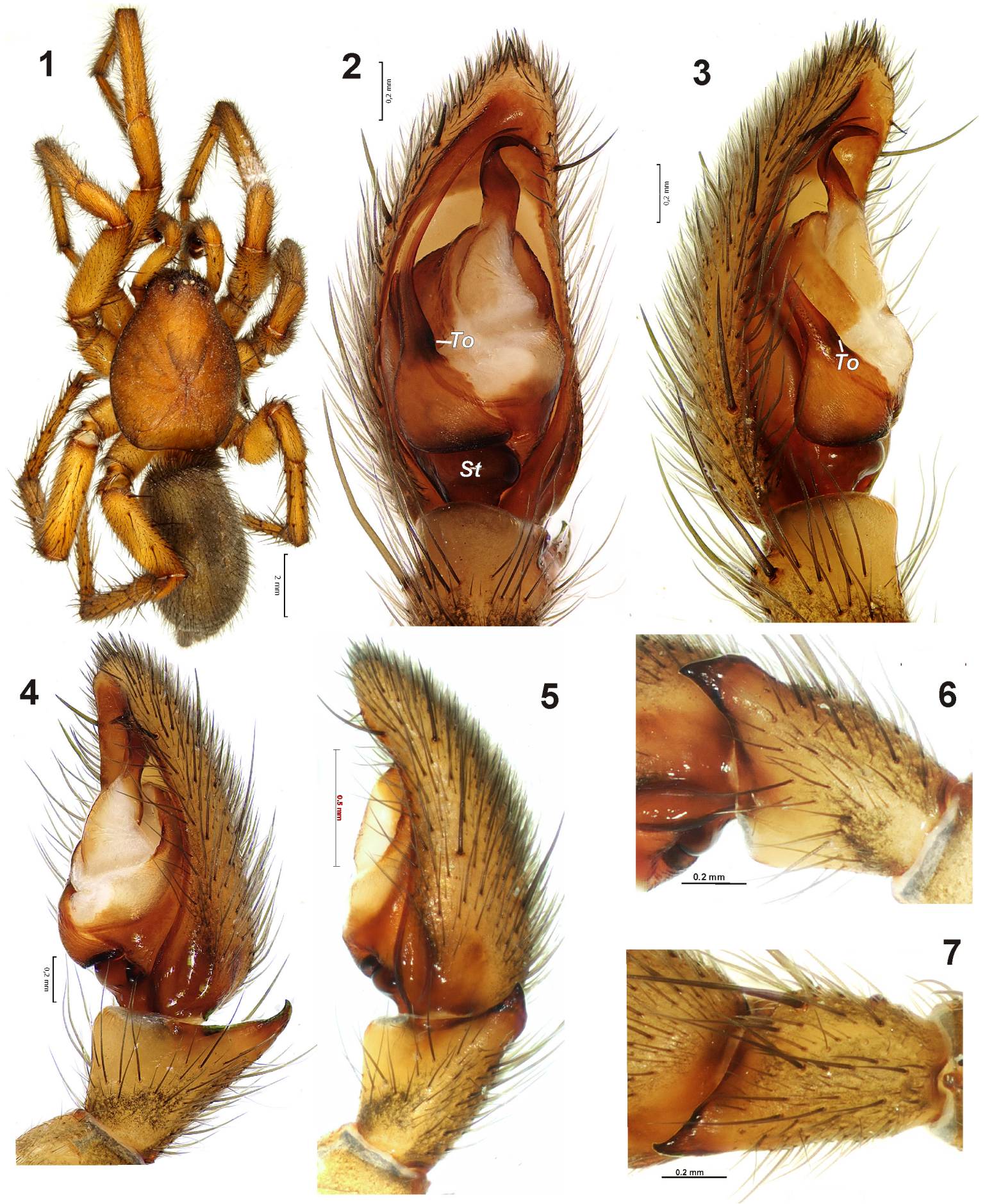

Figs 1-7. Gnaphosa ustyuzhanini sp.n.: 1 - habitus, dorsal; 2-4 - palp, ventral, prolateral and ventro-retrolateral; 5 - palp, retrolateral; 6-7 - palpal tibia, retrolateral and dorsal. Abbreviation: St - subtegulum, To - embolic tooth.

Рис. 1-7. Gnaphosa ustyuzhanini sp.n.: 1 - внешний вид, сверху; 2-4 - пальпа, снизу, пролатерально и вентро-ретролатерально; 5 - пальпа, ретролатерально; 6-7 - голень пальпы, ретролатерально и сверху. Сокращения: St - субтегулюм, To - зубчик эмболюса.

$91^{\circ} 11^{\prime} \mathrm{E}, 2600 \mathrm{~m}$, mountain stony steppe with rocky outcrops, under stone, 16.05.2012 (A.A. Fomichev). Paratype $\sigma^{7}$ ArshantynNuruu Mountain Range, $46^{\circ} 16^{\prime} 46^{\prime \prime} \mathrm{N}, 91^{\circ} 16^{\prime} 53^{\prime \prime} \mathrm{E}, 1560 \mathrm{~m}$, mountain stony steppe, under stone, 14.05.2012 (A.A. Fomichev).
OTHER MATERIAL. $\sigma^{7}$, Arshantyn-Nuruu Mountain Range, $46^{\circ} 21^{\prime} \mathrm{N}, 91^{\circ} 13^{\prime} \mathrm{E}, 1700-2000 \mathrm{~m}$, mountain stony steppe with rocky outcrops, under stone, 16.05.2012 (A.A. Fomichev). 

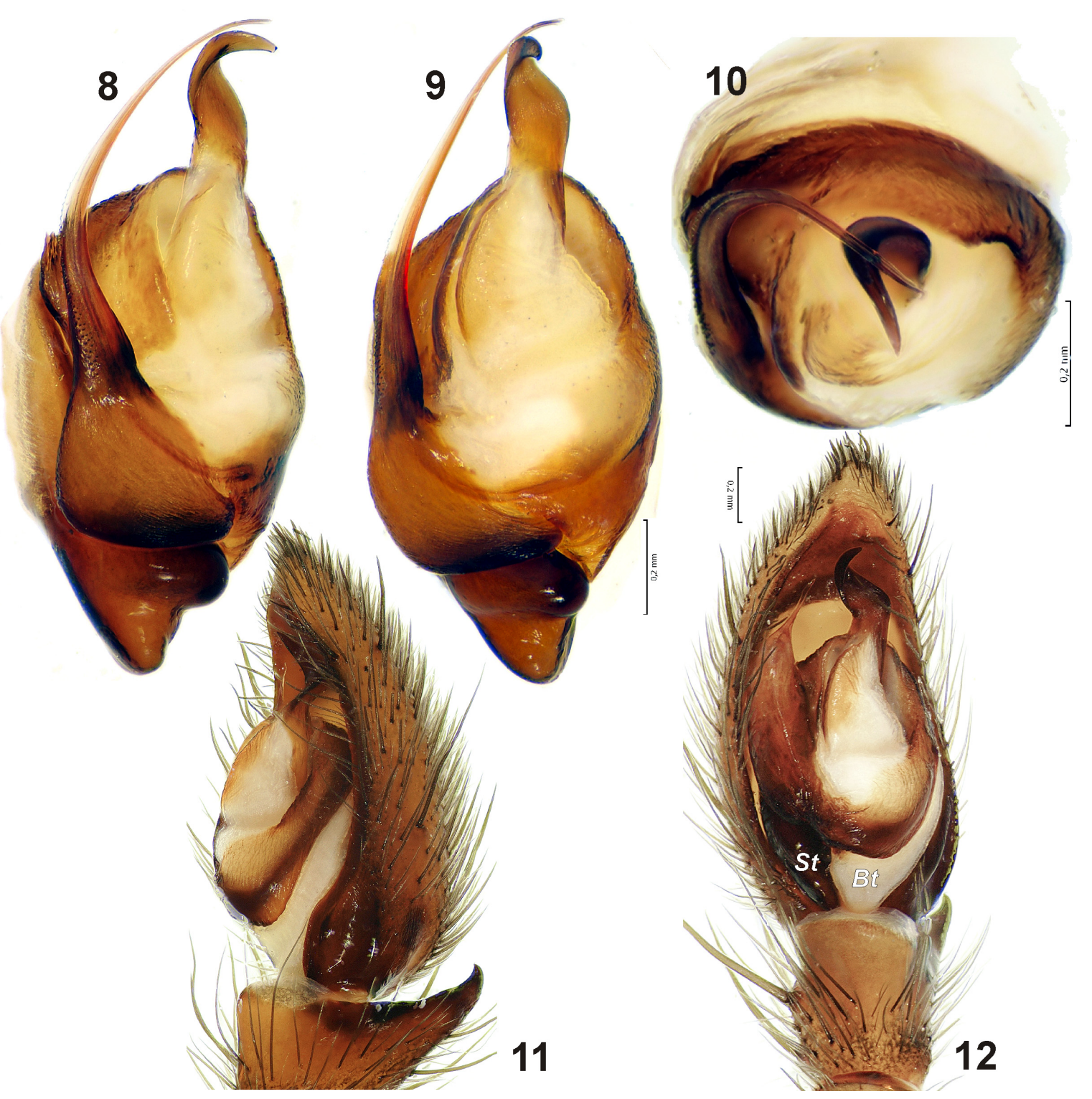

Figs 8-12. Gnaphosa ustyuzhanini sp.n. (8-10) and palp of presumably teratological specimen (11-12): 8-10 - bulbus, prolateral, ventral and from above; 11-12 — teratological palp, ventral and ventro-retrolateral. Abbreviations: Bt - base of tegulum, St subtegulum.

Рис. 8-12. Gnaphosa ustyuzhanini sp.n. (8-10) и уродливая пальпа (11-12): 8-10 - бульбус, пролатерально, снизу и сверху; 11-12 - уродливая пальпа, снизу и вентро-ретролатерально. Сокращения: $B t-$ основание тегулюма, $S t-$ субтегулюм.

DIAGNOSIS. The new species belongs to the muscorum species group, based on the long whip-like embolus, occupying most of the prolateral side of the bulbus. The new species is most similar to G. muscorum L. Koch, 1866 and G. mandschurica Schenkel, 1963. From the former species it differs by lacking a spur on the base of embolus and by having a more prominent median apophysis. From G. mandschurica it differs by having a shorter embolus and a shorter tibial apophysis.

DESCRIPTION. Male (holotype). Total length 9. Carapace: 5.0 long, 3.7 wide. Coloration: carapace, sternum, labium and maxillae brown, chelicerae dark brown. Legs light brown (Fig. 1). Abdomen grey. Legs spination: femora: I d1-1-1, p0-1-2; II d1-1-1, p0-1-1, r0-1-0; III, IV d1-1-1, p0-1-1, r0-1-1; patellae: III, IV p1-0, r1-0; tibiae: I, II p1-0-1, r1-0-0, v2-2-2; III d1-10, p3-2-2, r2-1-1, v2-2-2; IV d1-1-0, p3-3-2, r2-3-3, v2-2-2; metatarsi: I v2-2-0; II p0-1-0, v2-2-0; III d1-20, p1-2-0 1 subapical and 1 apical, r1-1-0 1 subapical and 1 apical, v2-1-2 2 apical; IV d2-2-0, p3-1-1 1 subapical and 1 apical, r3-0-1 1 subapical and 1 apical, v2-1-2 2 apical. 
Leg articles:

\begin{tabular}{|l|c|c|c|c|c|c|}
\hline & Femur & Patella & Tibia & Metatarsus & Tarsus & Total \\
\hline I & 4 & 2.1 & 3.35 & 3.1 & 2.25 & 14.8 \\
\hline II & 3.7 & 1.9 & 3.1 & 3.05 & 2.2 & 13.95 \\
\hline III & 3.4 & 1.8 & 2.6 & 3.4 & 2.05 & 13.25 \\
\hline IV & 4.3 & 2.2 & 3.75 & 5.25 & 2.55 & 18.05 \\
\hline
\end{tabular}

Palp as an Figs 2-10; tibial apophysis short (less than $1 / 2$ of tibia) with slightly bent and sharply pointed tip, upper $1 / 2$ triangle-shaped; median apophysis large, flattened in the upper part; base of embolus with very small almost indistinct tooth (To); basal part of embolus with fine teeth, prolateral membranous part of embolus serrated.

Female unknown.

COMMENT. We have a Gnaphosa specimen from the same mountain range which has presumably a teratological palp (Figs 11-12), with a poorly developed subtegulum $(S t)$, an unsclerotized base of the tegulum $(B t)$, the base of the embolus shifted up and a short embolus. However, the tibial and median apophyses look the same, or almost the same, as in the holotype. Hence, it is not absolutely clear if it belongs to the same new species. It also has a different leg spination pattern.

There is a small possibility that this species may be conspecific with G. rasnitsyni Marusik, 1993 known only from females from the Bayankhongor and Central Aimags.

DISTRIBUTION. Only the type locality (Arshantyn-Nuruu Mountain Range). It is interesting to note that this small mountain range (45-50 km length) on the north of Dzhungarian Gobi Desert has several known endemics in its entomofauna [Yakovlev, 2012].

ACKNOWLEDGEMENTS. We thank R.V. Yakovlev (Barnaul, Russia), A.N. Nakonechnyi (Novosibirsk, Russia), A.I. Shmakov (Barnaul, Russia), G.G. Khabiev (Aktash, Russia), U. Beket (Bayan-Ulegei, Mongolia) for organizing and undertaking an expedition to Mongolia, in which the material treated in this paper was collected. Also, we thank
S. Koponen (University of Turku) and R.Yu. Dudko (ISEA) for providing institutional facilities. An earlier draft of manuscript was reviewed by M.M. Kovblyuk (Simferopol) and G.N. Azarkina (Novosibirsk). English of the final draft was kindly checked by David Penney, Manchester, UK. This work was supported in part by the Russian Foundation for Basic Research (grants \#\# 11-0401716 and 12-04-01548) and the Far Eastern Federal University.

\section{References}

Loksa I. 1965. Ergebnisse der zoologischen Forschungen von Dr. Z. Kaszab in der Mongolei. 41. Araneae // Reichenbachia. Bd.7. Nr.1. S.1-32.

Marusik Yu.M. 1993. Three new wandering spider species (Araneae: Lycosidae, Gnaphosidae) from Mongolia // Arthropoda Selecta. Vol.2. No.1. P.77-81.

Marusik Yu.M., Koponen S. 2001. Description of a new species and new records of some species of the genus Gnaphosa (Araneae: Ganphosidae) from east Palearctic //Acta arachnologica. Vol.50. No.2. P.135-144.

Marusik Yu.M., Logunov D.V. 1995. Gnaphosid spiders from Tuva and adjacent territories, Russia // Beitr. Araneol. Bd.4. P.177210.

Marusik Yu.M., Logunov D.V. 2006. On the spiders collected in Mongolia by Dr. Z. Kaszab during expeditions in 1966-1968 (Arachnida, Aranei (excluding Lycosidae)) // Arthropoda Selecta.Vol.15. No.1. P.39-57.

Ovtsharenko V.I., Platnick N.I., Song D.X. 1992. A review of the North Asian ground spiders of the genus Gnaphosa (Araneae, Gnaphosidae) // Bulletin of the American Museum of Natural History. No.212. P.1-88.

Platnick N.I. 2013. The World Spider Catalog, Version 13.5. American Museum of Natural History, New York. Online at http:// research.amnh.org/iz/spiders/catalog/.

Platnick N.I., Shadab M.U. 1975. A revision of the spider genus Gnaphosa (Araneae, Gnaphosidae) in America // Bulletin of the American Museum of Natural History. No.155. P.1-66.

Song D.X., Zhu M.S., Zhang F. 2004. Fauna Sinica: Invertebrata Vol.39: Arachnida: Araneae: Gnaphosidae. Beijing: Science Press. 362 pp. [in Chinese]

Yakovlev R.V. 2012 [Butterflies (Lepidoptera: Papilionidea) of Arshantyn-Nuruu Range (Western Mongolia)] // Amurian zoological journal. Vol.4. No.1. P.54-60 [in Russian].

Responsible editor K.G. Mikhailov 